\title{
Health risks associated with high waist circumference: A systematic review
}

\author{
Darsini Darsini, ${ }^{1}$ Hamidah Hamidah, ${ }^{2}$ Hari Basuki Notobroto, ${ }^{3}$ Eko Agus Cahyono ${ }^{4}$ \\ ${ }^{1}$ Doctoral Program of Public Health, Faculty of Public Health; ${ }^{2}$ Department of Psychology, Faculty of \\ Psychology; ${ }^{3}$ Department of Biostatistics and Population, Faculty of Public Health, Universitas Airlangga, \\ Surabaya; ${ }^{4}$ Department of Nursing, Nursing Academy Dian Husada, Mojokerto, Indonesia
}

\begin{abstract}
Obesity is a health disorder characterized by an increase in body weight, measured by waist circumference. High waist circumference is linked to potential development of non-communicable diseases. A systematic review study was used to explore health risks of high waist circumference through Google Scholar, Science Direct, Pubmed, and Proquest. Findings show that high waist circumference increased the risks of developing hypertension, type 2 diabetes mellitus, hypercholesterolemia, joint pain, low back pain, and hyperuricemia. It is recommended that government increase their role in raising public awareness to maintain healthy lifestyle.
\end{abstract}

\section{Introduction}

Indonesia has adopted long-term development directives known as Sustainable Development Goals (SDGs). It is a comprehensive global action acknowledged by world leaders, including ending poverty, reducing inequality, and protecting the environment. SDG contains 17 goals and 169 targets, which are all expected to be achieved by $2030 .^{1}$ A key indicator of this program is good health and well-being, therefore to achieve this aim, all Ministries in Indonesia decided to collaborate to accomplish the targets of the Sustainable Development Goals (SDGs). ${ }^{2}$ The SDG and other dimensions are integrated into the national development agenda from planning to implementation. Conversely, at the national level, Indonesia has 9 priority elements in the agenda, better known as the Nawa Cita Program, which is prioritized for high-risk community members. ${ }^{3}$

The success of SDGs is a form of Millennium Development Goals (MDGs) achievement, and it indirectly had an impact on the lifestyle of the citizens. Subsequently, the ease of access to services in various fields, including transportation and technology, makes citizens become more dependent on technology. This led to the habit of buying and consuming more fast food, thereby abandoning the behavior of cooking and eating healthy. ${ }^{4,5}$ The impact of eating fast food leads to the occurrence of obesity in the community. ${ }^{6,7}$
Obesity is a health disorder characterized by an increase in body weight, measured by waist circumference. It occurs due to the accumulation of fat in the body caused by the excessive intake of calories. ${ }^{8}$ Furthermore, obesity is an imbalance condition between height and weight due to the excessive amount of body fat, generally piled up in the subcutaneous tissues around the organs, and sometimes infiltrates into these organs. Its occurrence in the community indirectly triggers the emergence of chronic diseases. ${ }^{9}$ General obesity is detected through BMI indicators $30.0-34.9,{ }^{8}$ while the waist and hip circumference ratio (RLPP) detects the central/abdominal obesity. World Health Organization (WHO) determines the healthy limit of the waist and hip circumference ratio of Asian countries to be $90 \mathrm{~cm}$ for men and 80 $\mathrm{cm}$ for women. ${ }^{8}$ Obesity increases blood pressure and triglyceride levels, which subsequently leads to cardiovascular diseases. ${ }^{10} \mathrm{~A}$ certain means of assessing the mass of abdominal subcutaneous and intra-abdominal fat is by measuring the waist circumference. Intra-abdominal fat produces certain proteins and hormones, namely adipokine, inflammation, angiotensinogen, and cortisol, which are associated with cardiometabolic diseases such as dyslipidemia, coronary heart diseases, and hypertension. ${ }^{11-13}$

Additionally, numerous scientific studies have been conducted in order to compare anthropometric conditions and the potential health risks associated with high waist circumference. ${ }^{14-17}$ Some of the guidelines used to measure risks associated with high waist circumference are the WHtR (Waist To Height Ratio) and WC (Waist Circumference). WHtR and WC are anthropometric measurements that are widely used to assess their conditions. ${ }^{14}$ The research conducted by Shalini et al stated that the anthropometric method that is ideal for people in Asia is the WC (Waist Circumference). ${ }^{18}$ The purpose of this study was to identify health risks related to high waist circumference.

\section{Design and Methods}

A systematic review study was used to explore health risks of high waist circumference through Google Scholar, Science Direct, Pubmed, and Proquest. Furthermore, the keywords used in the Indonesian contexts are "abdominal circumference," "waist circumference," "risk factors," "relationship" and "influence"

Significance for public health

Waist circumference is a significant predictor of general health, and a more accurate method than BMI. This is a simpler method for providing early warning signs of cardiometabolic diseases. This paper explores health risks related to high waist circumference, such as hypertension, diabetes mellitus, hypercholesterolemia, joint pain, low back pain, and hyperuricemia. 
while those used in English are "Abdominal circumference," "waist circumference," "risk factor," "relationship" and "influence." The search data is also limited to articles that were published between 2009-2019. The search results from google scholar in accordance with the keywords and years of publication between 2009-2019, discovered as many as 1,270 articles, while 5 articles were obtained from direct science, 2,476 articles from proquest and 31 articles from pubmed. According to these keywords, "Pain Labor," "Pain Relief," "Non-Pharmacology", "Therapy," and publications from 2014-2018, the search results from google scholar discovered 795 articles, while 443 articles were obtained from Science Direct and 108 articles from Pubmed. The criteria for the inclusion of articles consist of research published from 20092019, full and open texts, authors, and an assessment of the feasibility study (Figure 1).

\section{Results}

According to the results from the data analysis, several health risks related to high waist circumference were discovered, such as hypertension, diabetes mellitus, hypercholesterolemia, joint and low back pains, hyperuricemia, and Obstructive Sleep Apnea Syndrome (OSAS) (Table 1).

\section{Hypertension}

Waist circumference has a significant relationship with systolic blood pressure $(\mathrm{r}=0.282$, P-value $<0.001) .{ }^{19}$ Oviyanti stated that there was moderate correlation strength between the ratio of hip/waist circumference and diastolic blood pressure of the male subjects $(\mathrm{r}=0.418$, P-value $<0.001) .{ }^{20}$ On the other hand, Sumayku et al reported that a significant relationship exists between waist circumference and systolic blood pressure $(\mathrm{r}=0.311, \mathrm{P}$-value $<0.000)$, and diastolic blood pressure $(\mathrm{r}=0.272$, $\mathrm{P}$-value $<0.002){ }^{21}$ In addition to that, the research conducted by Sari et al., reported an association between the abdominal circumference and systolic blood pressure of the male sample with moderate correlation strength $(r=0.417)$. High abdominal circumference affected the results of systolic blood pressure in the female sample with moderate correlation strength of $(\mathrm{r}=0.346) .{ }^{22}$ Subsequently, the study carried out by Borel et al, stated that an increase in the size of the abdominal circumference affected the incidence of hypertension (P-values $<0.0017, \mathrm{OR}=1.042$ (95\% CI1.015$1.068)) .^{23}$

\section{Diabetes mellitus}

Waist circumference also has a strong relationship with blood glucose levels $(r=0.664) .{ }^{19}$ Therefore, the greater the waist circumference, the higher the glucose level in the blood. Soetiarto et al., stated that a relationship exists between the incidence of Mellitus and an increase in abdominal circumference above normal limits, ${ }^{24}$ and the research conducted by Borel et al., reported that an increase in the size of the abdominal circumference affects the occurrence of type 2 diabetes mellitus (P-values $<$ 0.0330, OR: 1.026 (95\% CI1.002-1.051). ${ }^{23}$ The study conducted by Simbar et al, stated that a significant relationship exists between waist circumference and HDL levels with $\mathrm{P}$-value $<0.015$. $^{25}$

\section{Hypercholesterolemia}

Further studies show that waist circumference has a positive relationship with triglyceride levels $(\mathrm{r}=0.292, \mathrm{P}$-value $<0.005) .{ }^{19} \mathrm{It}$ is usually interpreted as the greater the waist circumference, the higher the triglyceride levels in an individual. According to Larasati and Alvina, a relationship exist between the ratio of the waist circumference and total cholesterol levels in adult humans (P-value $<0.001) .{ }^{26}$ Borel et al. also stated that a correlation exists between the ratio of the waist circumference, total cholesterol, LDL, and triglyceride levels. ${ }^{23}$ Furthermore, the results from a similar study conducted by Lee et al., also reported that the ratio of the hip circumference is an indicator of obesity because it is often related to an increased risk of chronic diseases due to its association with lipid abnormalities in the blood. ${ }^{27}$

\section{Joint and low back pains}

An increase in abdominal circumference affect the risk of osteoarthritis pain $(\mathrm{P}$-value $<0.001, \mathrm{OR}=7.20){ }^{28}$ Maizura also reported that a relationship exists between the condition of abdominal circumference and complaints such as low back pain $(\mathrm{LBP})^{29}$ and joint pain (P-value $<0.001, \mathrm{OR}=11.387,95 \% \mathrm{CI}$ $5.318-24.382) .{ }^{30}$ When the results from the values of the abdominal circumference are above the normal limit, it tends to trigger an increase in uric acid levels in the blood. Therefore, an increase in abdominal circumference is often assumed to be a risk factor associated with joint pain due to an increase in the uric acid levels.

\section{Hyperuricemia}

The research conducted by Rau et al, on the comparison of uric acid levels in obese and non-obese subjects, stated that the average level of uric acid in both the obese and non-obese groupswas detected to be 8.057 and 6.624 respectively, with a significance value of 0.009 . It means that the condition of obesity is indicated by abdominal circumference above the normal limit, and this increases the risk of hyperuricemia. ${ }^{31}$

\section{Obstructive Sleep Apnea Syndrome}

An increase in the size of the abdominal circumference has an effect on the incidence of OSAS (Obstructive Sleep Apnea Syndrome $)\left(\mathrm{P}<0,0001, \mathrm{OR}=1,044(95 \% \mathrm{CI}, 1.018-1.071){ }^{23}\right.$

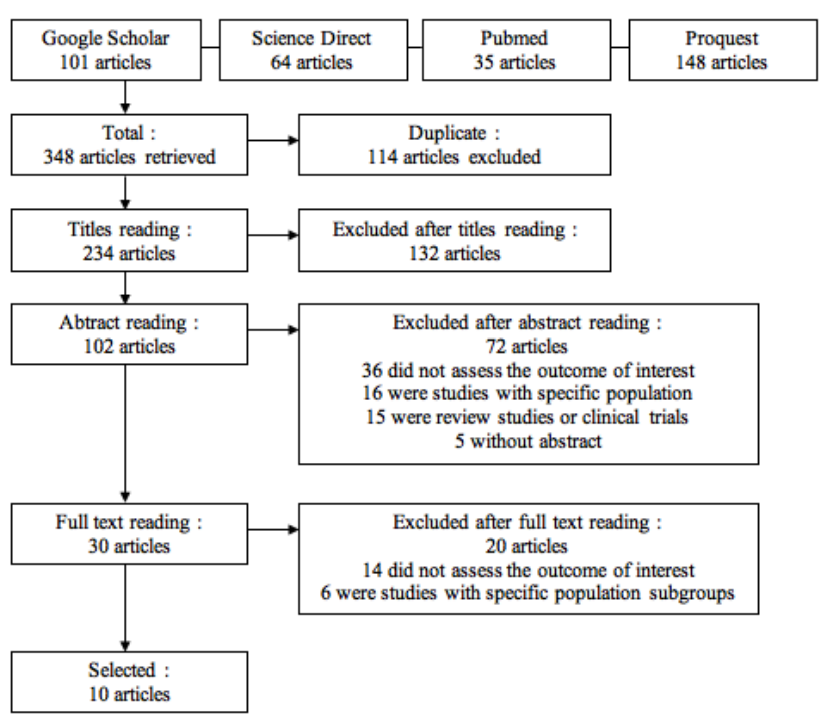

Figure 1. Flow chart of paper selection for the review. 
Table 1. Overview of studies included in the systematic review.

\begin{tabular}{|c|c|c|c|}
\hline Author, & Methods & $\begin{array}{l}\text { Waist circumference } \\
\text { measurement method }\end{array}$ & Result \\
\hline $\begin{array}{l}\text { Jalal } \\
\text { et al. } 2009\end{array}$ & $\begin{array}{l}\text { Cross-sectional study. } \\
\text { The study subjects were } 92 \\
\text { chosen by multistage random } \\
\text { sampling }\end{array}$ & Weight, height and waist size & $\begin{array}{l}\text { A positive association was found between waist } \\
\text { circumference and serum triglyceride, blood glucose and blood } \\
\text { pressure, however no correlation was found with HDL-cholesterol. }\end{array}$ \\
\hline Oviyanti, 2010 & $\begin{array}{l}\text { Cross-sectional study. } \\
\text { Determination of the sample is done } \\
\text { using consecutive sampling }\end{array}$ & $\begin{array}{l}\text { Blood pressure, waist circumference, } \\
\text { and hip circumference }\end{array}$ & $\begin{array}{l}\text { There is a relationship between waist circumference and the ratio } \\
\text { of hip circumference to systolic pressure, and the ratio of hip waist } \\
\text { to diastolic blood pressure in female subjects and the ratio of hip } \\
\text { waist circumference to diastolic pressure in male subjects. }\end{array}$ \\
\hline
\end{tabular}

Sumayku ,2014 This study is an analytical type with cross-section Height, weight, waist circumference and blood pressure There was a significant correlation between body mass index with systolic and diastolic blood pressure, systolic blood pressure and diastolic pressure and there also significant correlation between body mass index with waist circumference. The increase in body mass index and waist circumference may affect the blood pressure.

\begin{tabular}{lll} 
Sari et al. 2016 & $\begin{array}{l}\text { Cross sectional study, with } \\
\text { systematic random sampling }\end{array}$ & Abdominal circumference and blood pressure \\
\hline Borel et al. 2018 & Observational, transversal study & Height, weight, and hip, waist and neck circumference
\end{tabular}
The conclusion of this study is the increase in abdominal circumference puts the patient at risk of increased blood pressure.

Hip, waist and neck circumferences are correlated with BMI. Waist and neck circumferences were significantly associated with hypertension, type 2 diabetes and OSAS in univariate logistic regressions, waist-to-hip ratio with hypertension and type 2 diabetes. Neck circumference was the only marker significantly associated with all cardiometabolic risk markers.

\begin{tabular}{|c|c|c|}
\hline $\begin{array}{l}\text { Soetiarto } \\
\text { et al. } 2010\end{array}$ & Basic health research database analysis 2007 & Body mass index, abdominal circumference \\
\hline $\begin{array}{l}\text { Simbar et al. } \\
2015\end{array}$ & Descriptive cross sectional analytic study & $\begin{array}{l}\text { Secondary data of medical records of patients consisting } \\
\text { of measurements of hip circumference, lipid profile } \\
\text { (total cholesterol, HDL, LDL, triglycerides), } \\
\text { at the Endocrine Polyclinic at Prof. General } \\
\text { Hospital. R.D. Kandou Manado }\end{array}$ \\
\hline
\end{tabular}

\begin{tabular}{|c|c|c|c|}
\hline $\begin{array}{l}\text { Larasati, } \\
\text { and Alvina, } \\
2018\end{array}$ & Analytic study with cross-sectional design & Cholesterol level and hip waist circumference & $\begin{array}{l}\text { This study concludes that the hip waist circumference ratio is } \\
\text { associated with total cholesterol levels in adults. }\end{array}$ \\
\hline Lee et al. 2012 & Analytic study, time series & Percent body fat and body mass index & $\begin{array}{l}\text { The increased risks associated with fitness loss were also } \\
\text { somewhat attenuated when fatness was reduced. Both maintaining } \\
\text { or improving fitness and preventing fat gain are important to reduce } \\
\text { the risk of developing CVD risk factors in healthy adults. }\end{array}$ \\
\hline $\begin{array}{l}\text { Anggraini \& } \\
\text { Hendrati, } 2014\end{array}$ & Observation with case control design & $\begin{array}{l}\text { Knee osteoarthritis, obesity, gender, } \\
\text { age, physical activity, habit smoke }\end{array}$ & $\begin{array}{l}\text { The results showed significant relationship between } \\
\text { occurence of knee osteoarthritis with obesity, age, gender. } \\
\text { The conclusion there is relationship between obesity with knee } \\
\text { osteoarthritis. }\end{array}$ \\
\hline Maizura, 2015 & Cross sectional analytic study & $\begin{array}{l}\text { Neck score, body score, foot score, arm score, } \\
\text { final REBA score, age, gender, smoking, NPB history, } \\
\text { exercise habits, weight, waist circumference, height, } \\
\text { sitting height, body fat percent, length of } \\
\text { service and lighting }\end{array}$ & $\begin{array}{l}\text { Statistical test results show that variables related to complaints of } \\
\text { low back pain are neck score, body score, final REBA score, gender, } \\
\text { height, percent body fat, sitting height, and lighting. }\end{array}$ \\
\hline $\begin{array}{l}\text { Fauzan, \& Yuli } \\
\text { Kusumawati, } \\
2017\end{array}$ & Observational design with case control & $\begin{array}{l}\text { Body mass index (BMI), purine intake, } \\
\text { and exercise with the incidence of gout arthritis }\end{array}$ & $\begin{array}{l}\text { The results showed that there is a correlation between BMI with } \\
\text { the incidence of gout arthritis }\end{array}$ \\
\hline Rau et al. 2015 & Analytical study with a cross sectional design & Uric acid levels, body mass index & $\begin{array}{l}\text { The results showed that the average of uric acid levels in obese } \\
\text { group and in non-obese group. In the obese group, } 67 \% \text { had an } \\
\text { increase in uric acid level meanwhile in the non-obese group only } \\
38 \% \text {. In this study, the average of uric acid level in obese group was } \\
\text { significantly higher than in the non-obese group. }\end{array}$ \\
\hline
\end{tabular}

The adjusted $\mathrm{OR}$ of obesity based on waist circumference versus BMI were respectively as risk factors of DM among aged 25-64 in urban areas. The waist circumference is preferred to be measured in a survey, as a proxy indicator of DM burden, whenever the glucose load is not feasible to be carried out.

This research was not found significant relationship between circumference waist with total cholesterol levels, LDL levels, and triglyceride levels. However there is a significant relationship between waist circumference with HDL levels.

This study concludes that the hip waist circumference ratio is

The increased risks associated with fitness loss were also somewhat attenuated when fatness was reduced. Both maintaining or improving fitness and preventing fat gain are important to reduce occurence of knee osteoarthritis with obesity, age, gender. The conclusion there is relationship between obesity with knee

Statistical test results show that variables related to complaints of low back pain are neck score, body score, final REBA score, gender significantly higher than in the non-obese group. 


\section{Discussions}

\section{Hypertension}

The results from several studies stated that individuals with high waist circumference are at risk of experiencing hypertension. Hypertension occurs when the systolic and diastolic blood pressuresare above $140 \mathrm{mmHg}$ and $90 \mathrm{mmHg}$, respectively. This measurement needs to be taken within five minutes and when the individual is in a state of sufficient rest / calm. ${ }^{32,33}$ The current use of antihypertensive drugs determined it or when the measurements of the mean systolic and diastolic blood pressures are above 140 $\mathrm{mmHg}$ and $90 \mathrm{mmHg}$, respectively, taken at an interval of 3 minutes. The apparatus is usually placed on the non-dominant arm, with an appropriate-sized cuff after the patient had been sitting for about 5 minutes. ${ }^{23}$

Intra-abdominal fat plays an important role in raising blood pressure in obese people. This is because large abdominal circumference (high intra-abdominal fat) causes a decrease in adiponectin/anti atherogenic levels, and a decrease in the levels of this specific protein leads to an increase in blood pressure. Systolic blood pressure increases with an increase in the total peripheral resistance and causes large arterial stiffness. However, diastolic blood pressure increases with increased peripheral vascular resistance and decreases significant arterial stiffness.

Additionally, normal diastolic blood pressure is caused by a combination of the two, therefore it does not necessarily indicate cardiovascular risk. An increase in systolic blood pressure is more influential on the risk of cardiovascular diseases, especially when accompanied by age. After the age of 60 years, diastolic blood pressure tends to be stable and decreases while systolic blood pressure continues to increase. ${ }^{22}$

The waist circumference is an alternative measurement for body anthropometry as well as an obesity screening procedure. The criteria for obesity regarding the waist circumference is $>90$ $\mathrm{cm}$ for men and $>80 \mathrm{~cm}$ for women, while also the hip waist circumference ratio is $>0.90$ for men and $>0.80$ for women. In addition, IDF (Indonesia Development Forum) states that waist circumference is positively correlated to obesity than BMI. The mechanism of hypertension in obesity is played by several factors such as the expansion of body volume, increased cardiac output, decreased systemic vascular resistance, heightened activities of renin-angiotensin-aldosterone, an elevated level of leptin, increased free fatty acids, excessive secretion of endothelin-1, and disruption of natriuretic peptide activities. ${ }^{20}$

Several factors play a role in the mechanism of hypertension in obese people which include sympathetic nervous system, free fatty acids (FFA), leptin, and Natriuretic Peptide. The sympathetic nervous system acts as a mediator and causes excessive secretion of the androgenic hormones in obese individuals. There is also an increase in the kidney and muscle sympathetic nerve activities of these individuals. This indicates that increased activation of the sympathetic nervous system is responsible for the occurrence of hypertensive obesity syndrome. ${ }^{20}$ An increase in free fatty acids (FFA) is assumed to have an impact on the activation of the sympathetic nervous system. However, elevated sympathetic vascular responses cause hypertension. Central abdominal obesity in men occurs when the excess weight is on the free fatty acids (FFA) in the liver. It activates the hepatic afferent pathway, thereby inciting the sympathetic vascular tone, which in turn stimulates hypertension in obese individuals. ${ }^{34}$ Subsequently, leptin acts as a mediator between hypertension and obesity, which correlates with the amount of adipose tissue in the body. It also leads to an increase in the formation of angiotensin, which in turn increases cardiac output and causes blood pressure to rise. ${ }^{20}$ The breakdown of fatty acids in the tissues leads to the release of a factor in the liver, which tends to increase aldosterone synthesis. In addition, a study was conducted to show that fat cells have the ability to synthesize various components of RASS. This indicates that when there is an increase in the cell mass of obese individuals, the systemic angiotensin levels are triggered in order to mediate the occurrence of hypertension through the mechanism of $\mathrm{Na}$ retention. Natriuretic peptide plays a protective role in hypertension because it causes natriuresis and vasodilation. It also has an inhibitory effect on the central nervous system and RAAS. According to previous research, obese individuals over-expression of NPr-C leads to a decrease in plasma natriuretic peptide levels and changes that causes hypertension and $\mathrm{Na}$ retention. ${ }^{20}$

One of the characteristics of abdominal obesity/visceral fat is the enlargement of the fatty cells which secretes metabolic products, such as proinflammatory cytokines, procoagulants, inflammatory peptides, and angiotensinogen. The products of the fat cells and the increased free fatty acids in the plasma are responsible for the occurrence of hypertension in obese individuals. ${ }^{20}$ Furthermore, a study stated that visceral fat cells function as endocrine organs capable of producing pro-inflammatory cytokines TNF- $\alpha$ and IL- 6 as well as angiotensinogen. The presence of TNF- $\alpha$ and IL-6 leads to an increased level of asymmetric dimethylarginine (ADMA) and a competitive inhibitor of endogenous nitit oxide synthesis (NOS). ADMA activation of arginine causes an increase in citrullite metabolites and a decrease in nitrite oxide (NO), which functions as a vascular endothelial vasodilator. However, an increase in angiotensinogen production causes the activation of its renin system. Therefore, excessive secretion ofADMA and angiotensinogen, as well as a decrease in $\mathrm{NO}$, are responsible for the increase in a vascular endothelial tone, which shows the effect of obesity in mediating the occurrence of hypertension. ${ }^{20}$

\section{Diabetes mellitus}

The results showed that an increase in abdominal circumference above the normal limits leads to type 2 diabetes mellitus. The general increased risk of developing diabetes mellitus is due to the heightened prevalence of obesity. It this is marked by an increase in abdominal circumference above the normal limits. However, when the abdominal circumference is above the normal limit, it is identical to the incidence of obesity experienced and increases the risk of diabetes mellitus by 2.26 times more than in people that are not obese. The visceral fat around the organs in the abdomen tends to increase and alter plasma TNF $\alpha$ (necrotic tumor factor-alpha) levels. This, in turn, produces inflammatory cytokines and stimulates marker cells through interactions with its receptors, and this causes insulin resistance. ${ }^{23}$ This condition tends to damage the arteries and the liver. Increased plasma free fatty acids lead to the accumulation of intracellular lipids. The metabolites cause a decrease in insulin receptors. Excessive accumulation of lipids in pancreatic E cells causes dysregulation of insulin secretion, which is time-dependent. This causes insulin secretion to increase short-term lipid accumulation, and it decreases chronic accumulation. Furthermore, abnormalities in pancreatic E cells due to the free fatty acids cause apoptosis. The consequences of insulin resistance lead to hyperinsulinemia in the first stage, namely compensation, where the normoglycemic state can still be maintained. The second stage is decompensation, where the insulin is unable to sustain the normoglycemic state. However, the pancreas is still in a hypersecretion state, while hyperglycemic and hyperinsulinemia occurs. This causes impaired glucose tolerance and even type 2 diabetes mellitus. ${ }^{19,24,25}$ 


\section{Hypercholesterolemia}

The researches stated that an increase in abdominal circumference above the normal limit is at risk of triggering hypercholesterolemia. Visceral adipose tissue (VAT) has a strong correlation with most of the risks associated with metabolic diseases, especially hyperlipidemia, which is characterized by an increase in total cholesterol levels with or without an increased level of triglyceride concentrations or abnormal lipoprotein. This is consistent with the theory stating that intra-abdominal adipose tissue has more cells per unit mass, higher blood flow, more glucocorticoid (cortisal) receptors, and greater catecholamineinduced lipolysis compared to subcutaneous adipose tissue. Previous study mentioned that, an increase in visceral fat stimulates the liver (through portal circulation) to increase free fatty acid levels. ${ }^{26}$ However, increased VLDL secretion tends to trigger metabolic disorders or triglyceride and LDL storage. This disorder leads to intra-abdominal adipose tissue, which is more vulnerable to changes that occur in the accumulation and metabolism of lipids in the blood such as increased levels of total cholesterol or hypercholesterolemia.

Subsequently, increased fat in the stomach causes abnormalities in lipid metabolism. The main abnormalities of lipid fraction are an increase in total cholesterol levels, Low-Density Lipoprotein (LDL), triglyceride levels, and a decrease in HighDensity Lipoprotein (HDL) cholesterol levels. Fat in the abdominal cavity triggers cardiovascular diseases, and it is detected by the results from measurements of waist and hip circumference. Additionally, it is because they have large-sized adipocytes, namely the accumulation of triglyceride fat tissue, which easily causes an increase in lipolysis. This leads tothe excessive secretion of free fatty acids that tends to triggerits transfer to the muscles, thereby causing an increase in intracellular fatty acid metabolites such as diacylglycerol, ceramide, and acetyl koA. Therefore, the waist circumference is a better predictor of obesityrelated illnesses than BMI (Body Mass Index) and RLPP (Hip Waist Ratio). ${ }^{27}$

\section{Joint pain and low back pain}

The results showed that an increase in abdominal circumference above its normal limits causes an individual to be exposed to the risks of experiencing joint and low back pains. A person with an abdominal girth above the normal limits tends to be obese. Conversely, when obese people consume foods that contain fat, it is channeled into the abdomen, and when this happens continuously, it tends to accumulate. This also causes the lumbar to do more work in order to support the weight. Furthermore, when there is an increase in body weight, the spine tends to undergo more pressure. It can be more easily damaged, which is dangerous to its structure. However, people with abdominal circumference above the normal limits, are exposed to greater risks of developing low back pain. This is caused when the excessive weight of the individual is on the joints, thereby triggering low back pain. Excess body weight leads to traction in the soft tissues of the back. In addition, weight gains accompanied by a projection of the central gravity towards the front increases the weight borne by the paraspinal muscles (back muscles) and vertebrae (vertebrae). Therefore, excess pressure on the paraspinal muscles (back muscles) and vertebrae (vertebrae) triggers back pain or LBP (low back pain). ${ }^{28,30}$

\section{Hyperuricemia}

According to the results from the studies, it was stated that an increase in abdominal circumference above the normal limit puts obese individuals at risk of experiencing hyperuricemia. Increased levels of uric acid in individuals that have abdominal circumference above the normal limit are caused by a decrease in its excretion in the kidneys due to insulin resistance and hyperinsulinemia, which is common in overweight and obese individuals. Uric acid is the end product of purine catabolism. It originated from the degradation of purine nucleotides that occur in all cells. Conversely, the veins are produced by cells that contain xanthine oxidase, particularly the liver and small intestine. Hyperuricemia is defined as the condition/state in which the level of uric acid in the blood is more than $7.0 \mathrm{mg} / \mathrm{dL}$. It is classified as primary (idiopathic/genetic) and secondary hyperuricemia. ${ }^{35}$

The research conducted by Rau et al, stated that fatty tissues produce and excrete uric acid through xanthine axidoreductase (XOR) thereby causingits excessive production in obese people. ${ }^{31}$ Hyperuricemia in obesity occurs through insulin resistance. It creates an increase in the amount of free fatty acids released into the blood circulatory system of obese individuals. However, the excessive passage of free fatty acids into the muscles causes insulin resistance. Additionally, insulin resistance, hypoxia, and cell death induce specific changes in xanthine with the help of water and oxygen, which converts it into uric acid. It produces peroxide. Insulin also plays a role in increasing uric acid reabsorption in the proximal tubules of the kidney. Therefore, hyperinsulinemia in pre-diabetes leads to an increase in reabsorption, and this causes hyperuricemia. The daily consumption of food affects uric acid levels in the blood; consumption of seafood and meat also tends to affect gout. Subsequently, foods high in purines contribute to an increase in blood uric acid levels. This increase in individuals that have abdominal circumference above the normal limit is caused by a decrease in kidney function. Inadequate function of the kidney triggersthe uric acid levels due to interference of its excretion in the kidney. It is caused by a decrease in glomerular filtration, tubular excretion, and increased tubular reabsorption. ${ }^{31}$

\section{Obstructive Sleep Apnea Syndrome (OSAS)}

The results from studies conducted showed that an increase in the condition of the abdominal circumference above the normal limits causes the patient to be exposed to the risks of OSAS (Obstructive Sleep Apnea Syndrome). OSAS (Obstructive Sleep Apnea Syndrome) is a syndrome with episodes of apnea or hypopnea during sleep. Apnea is often caused by central or obstructive airway abnormalities or both. OSAS is the cessation of airflow to the nose and mouth despite the breathing efforts. Central apnea is the interruption of breathing, however, it is not accompanied by breathing effort due to the absence of breath stimulation. Partial obstruction of airflow causes obstructive hypoventilation. It causes hypoventilation, and hypoxia. Additionally, the term of obstructive hypoventilation identified as hypopnea (a reduction in airflow). The term OSAS is a syndrome of total or partial airway obstruction which causes significant physiological disorders with varying clinical effects. ${ }^{23}$ One of the causes of OSAS is obesity, which is the main one in adulthood. However, it is not the major cause of obesity in children. Its mechanism in obesity is caused by the narrowing of the upper respiratory tract due to the accumulation of fatty tissues in the muscles and soft tissues around the airway, as well as external compression of the neck and jaw. Obesity is measured by calculating BMI and the neck circumference. Conversely, the neck circumference compared to BMI is used to determine the OSAS. It is a known fact that large neck circumference or obesity in the upper region shows an increase in cardiovascular diseases. It is also assumed to be related to snoring and OSAS. It is also assumed that the accumulation of fat in the neck area causes the upper 
respiratory tract to become narrower. However, another possibility is that obese patients with large necks have velofarings and are prone to collapse because it triggers the upper airway obstruction during sleep.

Correspondence: Hari Basuki Notobroto, Department of Biostatistics and Population, Faculty of Public Health, Universitas Airlangga, Jl. Mulyorejo, Surabaya, Jawa Timur 60115, Indonesia.

Tel.: +62315920948, Fax: +62315924618.

E-mail: haribasuki.n@fkm.unair.ac.id.

Key words: Health Risks; High Waist Circumference; Systematic Review.

Contributions: The authors contributed equally.

Conflict of interest: The authors declare no potential conflict of interests.

Funding: Universitas Airlangga supported this research.

Acknowledgments: The authors are grateful to the University lecturers for their friendly support.

Clinical trials: This study does not involve any clinical trials.

Conference presentation: Part of this paper was presented at the $4^{\text {th }}$ International Symposium of Public Health, October 29-31, 2019, at the Griffith University, Gold Coast, Australia.

Received for publication: 6 March 2020.

Accepted for publication: 13 June 2020.

(Copyright: the Author(s), 2020

Licensee PAGEPress, Italy

Journal of Public Health Research 2020;9:1811

doi:10.4081/jphr.2020.1811

This work is licensed under a Creative Commons Attribution NonCommercial 4.0 License (CC BY-NC 4.0).

\section{Conclusions}

Findings show that high waist sircumference increased the risks of developing hypertension, type 2 diabetes mellitus, hypercholesterolemia, joint pain, low back pain, and hyperuricemia. It is recommended that government increase their role in raising public awareness to maintain healthy lifestyle.

\section{References}

1. United Nations Development Programme. Sustainable Development Goals. Available from: https:/www.undp.org/content/dam/undp/library/corporate/bro chure/SDGs_Booklet_Web_En.pdf. Accessed on: 16 August 2019.

2. Kementerian Koordinator Bidang Pembangunan Manusia dan Kebudayaan. Peraturan Presiden Republik Indonesia nomor 59 tahun 2017 tentang Pelaksanaan Pencapaian Tujuan Pembangunan Berkelanjutan. 2017. Available from: https://www.kemenkopmk.go.id/sites/default/files/produkhukum/Perpres\%20Nomor\%2059\%20Tahun\%202017\%20 tentang\%20\%20Pelaksanaan $\% 20$ Pencapaian\%20Tujuan\%20
Berkelanjutan\%20\%28TPB\%29.pdf. Accessed on: 16 August 2019.

3. Kementerian Komunikasi dan Informatika Republik Indonesia. Jadikan Indonesia Mandiri, Berkepribadian, dan Berdaulat. 2015. Available from: https://kominfo.go.id/content/detail/5629/jadikan-indonesia-mandiri-berkepribadiandan-berdaulat/0/infografis. Accessed on: 16 August 2019.

4. Gulati S, Misra A. Abdominal obesity and type 2 diabetes in Asian Indians: dietary strategies including edible oils, cooking practices and sugar intake. Eur J Clin Nutr 2017;71:850-7.

5. Suryana A, Ariani M, Lokollo EM. The role of modern markets in influencing lifestyles in Indonesia. Jurnal Penelitian dan Pengembangan Pertanian 2017;27:10-5.

6. Mohammadbeigi A, Asgarian A, Moshir E, et al. Fast food consumption and overweight/obesity prevalence in students and its association with general and abdominal obesity. J Prev Med Hyg 2018;59:E236.

7. Jia P, Luo M, Li Y, et al. Fast-food restaurant, unhealthy eating, and childhood obesity: A systematic review and meta-analysis. Obes Rev 2019. Available from: https://doi.org/10.1111/obr. 12944. Accessed on: 10 December 2019.

8. WHO. Obesity. 2020. Available from: https://www.who. int/topics/obesity/en/. Accessed on: 10 February 2020.

9. Hakkak R, Bell A. Obesity and the link to chronic disease development. J Obes Chronic Dis 2016;1:1-3.

10. Van Gaal LF, Mertens IL, Christophe E. Mechanisms linking obesity with cardiovascular disease. Nature 2006;444:875-80.

11. Xiao YQ, Liu Y, Zheng SL, et al. Relationship between hypertension and body mass index, waist circumference and waisthip ratio in middle-aged and elderly residents. Zhonghua liu xing bing xue za zhi 2016;37:1223-7.

12. Dong B, Wang Z, Yang Y, et al. Intensified association between waist circumference and hypertension in abdominally overweight children. Obes Res Clin Pract 2016;10:24-32.

13. Manios Y, Karatzi K, Protogerou A, et al. Prevalence of childhood hypertension and hypertension phenotypes by weight status and waist circumference: the Healthy Growth Study. Eur J Nutr 2018;57:1147-55.

14. Sebati B, Monyeki K, Kemper HCG, et al. Anthropometric indices for predicting cardiovascular risk factors: Ellisras longitudinal study. Am J Hum Biol 2019;31:e23293.

15. Frehner C, Cunha NM, Nagano FEZ, et al. Identifying and classifying anthropometric indicator for cardiovascular risk and coronary artery calcification: a protocol for a scoping review study. BMJ open 2019;9:e031993.

16. Niu G, Li J, Wang H, et al. Associations of A-FABP with anthropometric and metabolic indices and inflammatory cytokines in obese patients with newly diagnosed type 2 diabetes. BioMed Res Int 2016;2016:1-6.

17. Farello G, Antenucci A, Ceci F, et al. Anthropometric and metabolic parameters to distinguish metabolically healthy obese children from children with metabolic syndrome. Current Pediat Res 2017;21:158-63.

18. Shalini D, Ponnalagu O, Bi X, et al. Is waist circumference more strongly associated with metabolic risk factors than waist-to-height ratio in Asians? Nutrition 2019;60:30-4.

19. Jalal F, Liputo NI, Susanti N, et al. Lingkar pinggang, kadar glukosa darah, trigliserida dan tekanan darah pada etnis Minang di Kabupaten Padang Pariaman, Sumatera Barat. Media Medika Indonesiana 2009;43:129-36.

20. Oviyanti PN. Hubungan antara lingkar pinggang dan rasio lingkar pinggang panggul dengan tekanan darah pada subjek usia dewasa. 2010. Available from: https://core.ac.uk/download/pdf/16509133.pdf. Accessed on: 10 December 2019. 
21. Sumayku IM, Pandelaki K, Wongkar M. Hubungan indeks massa tubuh dan lingkar pinggang dengan tekanan darah pada mahasiswa Fakultas Kedokteran Universitas Sam Ratulangi. eCliniC 2014;2(2):1-5.

22. Sari MK, Lipoeto NI, Herman RB. Hubungan Lingkar Abdomen (Lingkar Perut) dengan Tekanan Darah. Jurnal Kesehatan Andalas 2016;5:456-61.

23. Borel A-L, Coumes S, Reche F, et al. Waist, neck circumferences, waist-to-hip ratio: Which is the best cardiometabolic risk marker in women with severe obesity? The SOON cohort. PloS one 2018;13:e206617.

24. Soetiarto F, Roselinda R, Suhardi S. Hubungan diabetes melitus dengan obesitas berdasarkan indeks massa tubuh dan lingkar pinggang data Riskesdas 2007. Buletin penelitian kesehatan 2010;38:36-42.

25. Simbar M, Pandelaki K, Wongkar M. Hubungan lingkar pinggang dengan profil lipid pada pasien diabetes melitus tipe 2. eCliniC 2015;3:1-4.

26. Larasati S, Alvina A. Rasio lingkar pinggang panggul berhubungan dengan kadar kolesterol total pada dewasa. Jurnal Biomedika dan Kesehatan 2018;1:126-32.

27. Lee D-c, Sui X, Church TS, et al. Changes in fitness and fatness on the development of cardiovascular disease risk factors: hypertension, metabolic syndrome, and hypercholesterolemia. J Am Coll Cardiol 2012;59:665-72.

28. Anggraini NE, Hendrati LY. Hubungan Obesitas dan FaktorFaktor Pada Individu dengan Kejadian Osteoarthritis Genu. Jurnal Berkala Epidemiologi 2014;2:93-104.
29. Maizura F. Faktor-Faktor yang Berhubungan dengan Keluhan Nyeri Punggung Bawah (NPB) pada Pekerja di PT. Bakrie Metal Industries tahun 2015. 2015. Available from: http://repository.uinjkt.ac.id/dspace/bitstream/123456789/296 32/1/FEBRIANA\%20MAIZURA-FKIK.pdf. Accessed on: 14 July 2019.

30. Fauzan A, Yuli Kusumawati S. Hubungan Indeks Massa Tubuh (IMT), Asupan Purin dan Olahraga dengan Kejadian Gout Arthritis pada Lansia di Wilayah Kerja Puskesmas Tanjungsari Pacitan. Surakarta: Universitas Muhammadiyah; 2017.

31. Rau E, Ongkowijaya J, Kawengian V. Perbandingan kadar asam urat pada subyek obes dan non-obes di Fakultas Kedokteran Universitas Sam Ratulangi Manado. e-CliniC 2015;3:1-7.

32. Chobanian AV, Bakris GL, Black HR, et al. The seventh report of the joint national committee on prevention, detection, evaluation, and treatment of high blood pressure: the JNC 7 report. Jama 2003;289:2560-71.

33. Kementerian Kesehatan Republik Indonesia. Hipertensi. Jakarta: Pusat Data dan Informasi Kementerian Kesehatan Republik Indonesia; 2014.

34. Kintscher U, Bramlage P, Paar WD, et al. Irbesartan for the treatment of hypertension in patients with the metabolic syndrome: a sub analysis of the Treat to Target post authorization survey. Prospective observational, two armed study in 14,200 patients. Cardiovasc Diabetol 2007;6:12.

35. Nasrul E, Sofitri S. Hiperurisemia pada Pra Diabetes. Jurnal Kesehatan Andalas 2012;1:86-91. 